\title{
Comparative Study of Microglia Activation Induced by Amyloid-Beta and Prion Peptides: Role in Neurodegeneration
}

\author{
Pedro Garção, ${ }^{1}$ Catarina R. Oliveira, ${ }^{1,2}$ and Paula Agostinho ${ }^{1,2 \star}$ \\ ${ }^{1}$ Center for Neuroscience and Cell Biology, University of Coimbra, Coimbra, Portugal \\ ${ }^{2}$ Faculty of Medicine, University of Coimbra, Coimbra, Portugal
}

The inflammatory responses in Alzheimer's disease (AD) and prion-related encephalopathies (PRE) are dominated by microglia activation. Several studies have reported that the amyloid-beta $(A \beta)$ peptides, which are associated with $A D$, and the pathogenic isoform of prion protein ( $\mathrm{PrP}^{\mathrm{Sc}}$ ) have a crucial role in neuronal death and gliosis that occur in both of these disorders. In this study, we investigate whether $A \beta$ and $\operatorname{PrP}^{\mathrm{Sc}}$ cause microglia activation per se and whether these amyloidogenic peptides differentially affect these immunoeffector cells. In addition, we also determined whether substances released by $A \beta-$ and PrPactivated microglia induce neuronal death. Cultures of rat brain microglia cells were treated with the synthetic peptides $A \beta_{1-40}, A \beta_{1-42}$ and $\operatorname{PrP}_{106-126}$ for different time periods. The lipopolysaccharide was used as a positive control of microglia activation. Our results show that $A \beta_{1-40}$ and $\mathrm{PrP}_{106-126}$ caused similar morphological changes in microglia and increased the production of nitric oxide and hydroperoxides. An increase on inducible nitric oxide synthase expression was also observed in microglia treated with $A \beta_{1-40}$ or $\mathrm{PrP}_{106}$. However, these peptides affected in a dif-

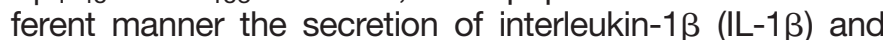
interleukin-6 (IL-6) secretion. In cocultures of microglia-neurons, it was observed that microglia treated with $A \beta_{1-40}$ or $\mathrm{PrP}_{106-126}$ induced a comparable extent of neuronal death. The neutralizing antibody for IL-6 significantly reduced the neuronal death induced by $A \beta$ - or PrP-activated microglia. Taken together, the data indicate that $A \beta$ and PrP peptides caused microglia activation and differentially affected cytokine secretion. The IL-6 released by reactive microglia caused neuronal injury. @ 2006 Wiley-Liss, Inc.

Key words: nitric oxide; reactive oxygen species; cytokines; neuroinflammation; neurotoxicity

Microglia are the immunocompetent cells of the CNS, playing an important role in brain homeostasis maintenance. These cells are very sensitive to changes in the surrounding environment and readily become activated in response to infection or injury (Streit, 2002; Liu and Hong, 2003). Microglia activation is a gradual process, involving cell proliferation and migration to the site of injury, as well as morphological and functional changes. Activated microglia have an amoeboid mor- phology, up-regulate several surface receptors, and secrete a large variety of soluble factors, such as cytokines, chemokines, proteases, reactive oxygen species (ROS), and nitric oxide (NO; Lee et al., 2002; Davalos et al., 2005). Although some of these factors promote neuronal and glial survival, most are neurotoxic and proinflammatory (Liu and Hong, 2003; van Rossum and Hanisch, 2004). Thus, it is widely accepted that microglia activation provides an initial protective role, whereas a persistent activation of these cells and the consequent sustained secretion of inflammatory factors contribute to neuronal death that occurs in neurodegenerative diseases.

Prion-related encephalopathies (PRE) and Alzheimer's disease (AD) are neurodegenerative disorders characterized neuropathologically by the presence of extracellular amyloid deposits, extensive neuronal loss, and gliosis. In $\mathrm{AD}$, the amyloid deposits are composed of amyloid-beta $(A \beta)$ peptides (40-42 amino acids), which result from the abnormal proteolytic cleavage of amyloid precursor protein, whereas, in PRE, the amyloid deposits are constituted mainly of the scrapie isoform of prion protein $\left(\mathrm{PrP}^{\mathrm{Sc}}\right)$, a conformational variant of the cellular prion protein $\left(\mathrm{PrP}^{\mathrm{C}}\right)$. The amyloid deposits are generally colocalized with reactive microglia, inflammatory factors, and dystrophic neurites (Nelson et al., 2002; Liu and Hong, 2003). Increasing evidence suggests that microglia activation is concomitant with $\mathrm{A} \beta$ and $\operatorname{PrP}^{\mathrm{Sc}}$ deposition and precedes neuronal death (Marella and Chabry, 2004; Veerhuis et al., 2005). Indeed, microglia are considered to be involved in neuroinflammation and, consequently, in the progression of $\mathrm{AD}$ and PRE (Eikelenboom et al., 2002; Veerhuis et al., 2005).

Contract grant sponsor: "Gabinete de Apoio à Investigação (GAI)," Faculty of Medicine, University of Coimbra; Contract grant sponsor: FCT (Portuguese Research Council).

*Correspondence to: Paula Agostinho, Center for Neuroscience and Cell Biology of Coimbra, Faculty of Medicine, University of Coimbra, 3004504 Coimbra, Portugal. E-mail: pagost@cnc.cj.uc.pt

Received 31 October 2005; Revised 1 March 2006; Accepted 8 March 2006

Published online 21 April 2006 in Wiley InterScience (www. interscience.wiley.com). DOI: 10.1002/jnr.20870 
In the present study, we analyzed whether $A \beta$ and PrP differentially activate microglia cells and whether microglia treated with these peptides trigger neuronal death. The synthetic peptides $A \beta_{1-40}, A \beta_{1-42}$, and $\operatorname{PrP}_{106-126}$, which are widely used to mimic the effect of $\mathrm{A} \beta$ and $\operatorname{PrP}^{\mathrm{Sc}}$, were utilized to stimulate cultured rat brain microglia cells. Morphological changes and molecular responses induced by these peptides in microglia cells were determined and compared with microglial reactions to lipopolysaccharide (LPS), a well-known inductor of inflammation. Cocultures of microglia/neurons were used to investigate whether the substances released by $\mathrm{A} \beta$ - and $\mathrm{PrP}$-activated microglia cause neurodegeneration.

\section{MATERIALS AND METHODS}

\section{Materials}

Neurobasal medium and B-27 supplement were purchased from Gibco (Paisley, United Kingdom). Synthetic peptides of $\mathrm{A} \beta$ and $\mathrm{PrP}$ were from Bachem (Bubendorf, Switzerland). The rat anti-ED1 (clone ED1), rabbit anti- inducible nitric oxide synthase (iNOS; clone $\mathrm{pAb}$ ), and rat anti-interleukin-6 (IL6) antibodies were obtained from Serotec (Oxford, United Kingdom), BD Biosciences (Erembodegem, Belgium), and R\&D Systems (Minneapolis, MN), respectively. Alexa Fluor IgG conjugated secondary antibodies, $2^{\prime}, 7^{\prime}$-dichlorofluorescin diacetate, Amplex red hydrogen peroxide/peroxidase assay kit (A-22188), and Hoechst 33342 were acquired from Molecular Probes (Leiden, The Netherlands). The fluorescent mounting medium was from DakoCytomation (Glostrup, Denmark). ELISA kits for rat interleukins were obtained from R\&D Systems (Abingdon, United Kingdom). Millicell culture plate inserts were from Millipore (Bedford, MA). Reagents and apparatus used in immunoblotting assays were obtained from Bio-Rad (Hercules, CA), whereas PVDF membranes, alkaline phosphatase-linked antimouse secondary antibody, and the enhanced chemifluorescence (ECF) reagent were from Amersham Biosciences (Buckinghamshire, United Kingdom). Percoll solution was also purchased from Amersham Biosciences. All other reagents, including LPS (Escherichia coli O26:B6), were from Sigma Chemical Co. (St. Louis, MO).

\section{Microglia Cell Cultures}

Primary microglial cell cultures were obtained from neonatal Wistar rats 5-7 days old, according to the method described by Kingham and colleagues (1999), with some modifications. In brief, after cervical dislocation and decapitation of rats, the brains were removed and placed in ice-cold phosphate buffer solution [PBS (in $\mathrm{mM}$ ) $140 \mathrm{NaCl}, 4 \mathrm{KCl}, 8.5$ $\mathrm{KH}_{2} \mathrm{PO}_{4}, 7.4, \mathrm{Na}_{2} \mathrm{HPO}_{4}, \mathrm{pH}$ 7.4]. After removal of the cerebellum, they were cut into small pieces and homogenized. The brain homogenate was then centrifuged at $500 \mathrm{~g}$ for $10 \mathrm{~min}$ at $4^{\circ} \mathrm{C}$. The pellet was resuspended in a $70 \%$ Percoll solution. The $70 \%$ Percoll-cell mixture was then overlaid with $35 \%$ Percoll and finally with PBS. The Percoll gradient formed was centrifuged at $1,300 \mathrm{~g}$ for $45 \mathrm{~min}$ at $20^{\circ} \mathrm{C}$, and the microglia cells were collected at the $35 \% / 70 \%$ interface. Then, the cells were mechanically dissociated, through a 5-ml glass pipette, and washed in PBS (five times the cell volume collected) at $500 \mathrm{~g}$ for $10 \mathrm{~min}$ at $20^{\circ} \mathrm{C}$. Dissociated microglia cells were ressuspended in astrocytes conditioned medium (ACM) and counted in a hemocitometer. The ACM was obtained from rat brain astrocytes cultured in DMEM medium supplemented with $10 \%$ fetal calf serum and penicillin $(100 \mathrm{U} / \mathrm{ml})$ and streptomycin $(100 \mu \mathrm{g} / \mathrm{ml}$; Sastradipura et al., 1998). The microglia cells were cultured in filtered ACM ( $\left.\mathrm{pH}^{7.4}\right)$ at $37^{\circ} \mathrm{C}$ in an atmosphere containing $95 \%$ air and $5 \% \mathrm{CO}_{2}$. The cells were plated in plastic plates or in cell culture inserts (membrane pore size $0.4 \mu \mathrm{m}$ ) at a density of $0.2 \times 10^{6}$ cells/ $\mathrm{cm}^{2}$ or in glass coverslips at $0.1 \times 10^{6}$ cells $/ \mathrm{cm}^{2}$. Twenty-four hours after plating, the medium was changed and the cells were treated with the peptides or LPS for different periods of time. The morphological analysis and immunoreactivity toward microglial marker complement receptor type 3 using anti-CD11b monoclonal antibody (1:50; Serotec) and antiglial fibrillary acid protein (GFAP) polyclonal antibody (1:200; DakoCytomation) had shown that these cultures are constituted of $>95 \%$ microglia (data not shown).

\section{Neuron-Microglia Cocultures}

Primary cultures of cortical cells were prepared from 15-16-day embryos of Wistar rats according to the method described by Agostinho and Oliveira (2003). Cortical cells were cultured in Neurobasal medium with $2 \mathrm{mM} \mathrm{L}$-glutamine, $2 \%$ B27 supplement, penicillin $(100 \mathrm{U} / \mathrm{ml})$, and streptomycin $(100 \mu \mathrm{g} / \mathrm{ml})$. The neurons were plated on poly-L-lysine $(0.1 \mathrm{mg} / \mathrm{ml})$-coated coverslips at a density of $0.6 \times 10^{6}$ cells $/ \mathrm{cm}^{2}$ and maintained at $37^{\circ} \mathrm{C}$ in a humidified atmosphere of $5 \% \mathrm{CO}_{2} / 95 \%$ air. Microglia cells cultured in inserts, for 1 day, were placed into the wells containing the neurons, with 5 days in culture. These cocultures were maintained in ACM medium, and the treatment with the peptides or with LPS started $16 \mathrm{hr}$ afterward. The distance between the microglia (inserts) and neurons (coverslips) was approximately $1 \mathrm{~mm}$.

\section{Treatment With Peptides}

Cultured microglia cells were treated with $A \beta_{1-40}$ or $A \beta_{40-1}(5 \mu \mathrm{M}), A \beta_{1-42}(0.5 \mu \mathrm{M}), \operatorname{PrP}_{106-126}(25 \mu \mathrm{M})$, and scrambled $\operatorname{PrP}(25 \mu \mathrm{M})$ for different periods ranging from 3 to $24 \mathrm{hr}$, as indicated in the figure legends. The peptides were added into culture medium at the second culturing day. The peptides were reconstituted according to the manufacturer's instructions, and $A \beta_{1-40}$ or $A \beta_{40-1}$ peptides were aged in PBS buffer, in a stock concentration of $231 \mu \mathrm{M}$, for 7 days at $37^{\circ} \mathrm{C}$ to obtain fibrillar $\mathrm{A} \beta$. LPS $(0.1 \mu \mathrm{g} / \mathrm{ml})$ was added to cultured microglia as indicated for peptides. Cells not treated (control) or treated with 2.1\% PBS (vehicle control) were used as controls.

\section{Immunocytochemistry}

Microglia cells cultured in glass coverslips were treated with peptides or LPS. Then, the cells were washed with PBS and fixed with a $4 \%$ paraformaldehyde solution ( $\mathrm{pH}$ 7.4) for $30 \mathrm{~min}$ at room temperature (RT). The cells were permeabilized with PBS- $0.2 \%$ Triton $\mathrm{X}-100$ for $2 \mathrm{~min}$ at RT, and blocked with $0.1 \%$ bovine serum albumin (BSA) in PBS 
Control

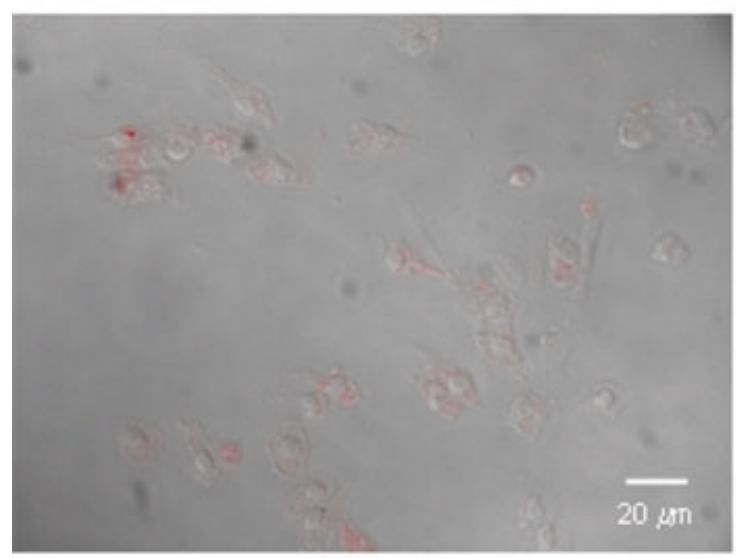

\section{LPS}

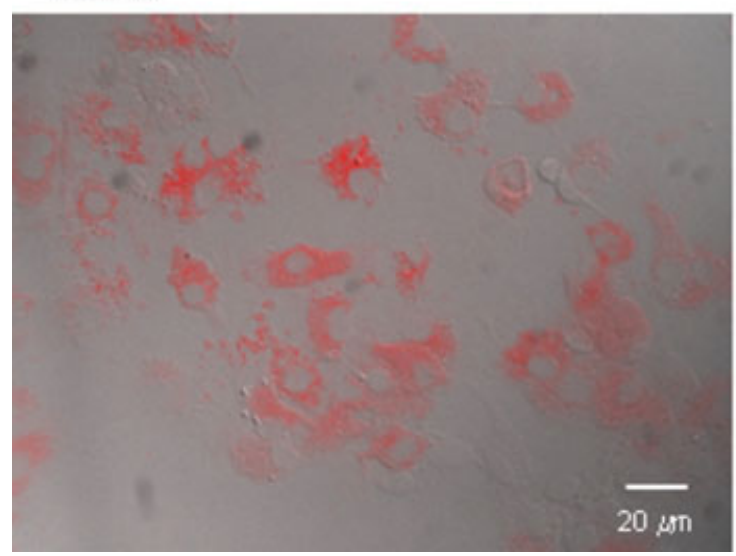

Fig. 1. Effect of $A \beta$ and PrP peptides on microglial morphology. Cultured rat brain microglia cells were treated or not (control) with $A \beta_{1-40}$ $(5 \mu \mathrm{M})$ or $\operatorname{PrP}_{106-126}(25 \mu \mathrm{M})$ for $3 \mathrm{hr}$. LPS $(0.1 \mu \mathrm{g} / \mathrm{ml})$ was used to treat the cells for the same period, because it is a classical inductor of inflammation (positive control). Control and treated cells were fixed and immunostained for ED-1 (microglia activation marker), as de-

before incubation with a primary antibody for $1 \mathrm{hr}$ at RT. The anti-ED1 (1:500) and anti-iNOS (1:500) monoclonal antibodies was used to recognize an antigen predominant in activated microglia and iNOS, respectively. After being washed in PBS to remove the unbound antibody, they were incubated with labelled anti-mouse Alexa Fluor 594 (for antiED1) or anti-rabbit Alexa Fluor 488 (for anti-iNOS) $\operatorname{lgG}$ antibodies (1:500) for $1 \mathrm{hr}$ at RT. Finally, the cells were mounted with the DakoCytomation fluorescent medium and visualized via fluorescence microscopy. Figures 1 and 4 show representative images of each experimental condition obtained in three or four independent experiments.

\section{Western Blotting}

Treated microglia cells were lysed with ice-cold isolation buffer $[250 \mathrm{mM}$ sucrose, $20 \mathrm{mM}$ HEPES, $10 \mathrm{mM} \mathrm{KCl}$, $1.5 \mathrm{mM} \mathrm{MgCl} 2$ (pH 7.4), $1 \mathrm{mM}$ dithiothreitol (DTT), $1 \mathrm{mM}$

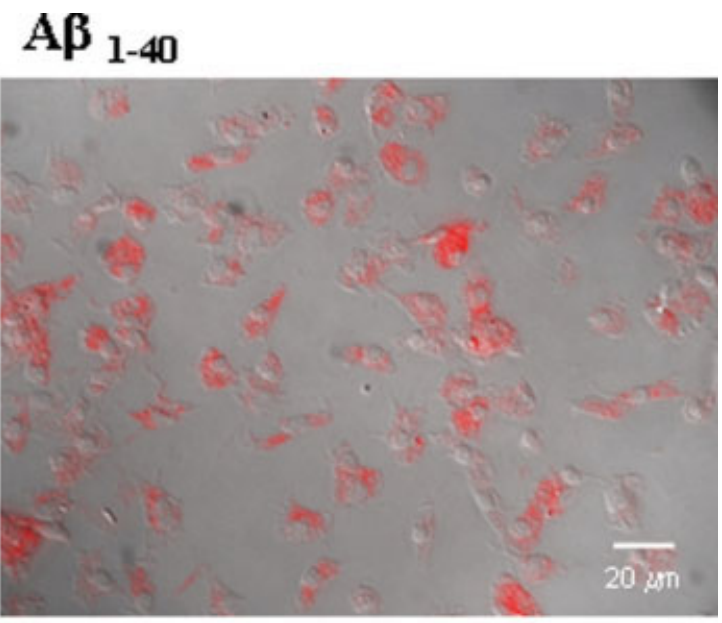

\section{$\operatorname{PrP}_{106-126}$}

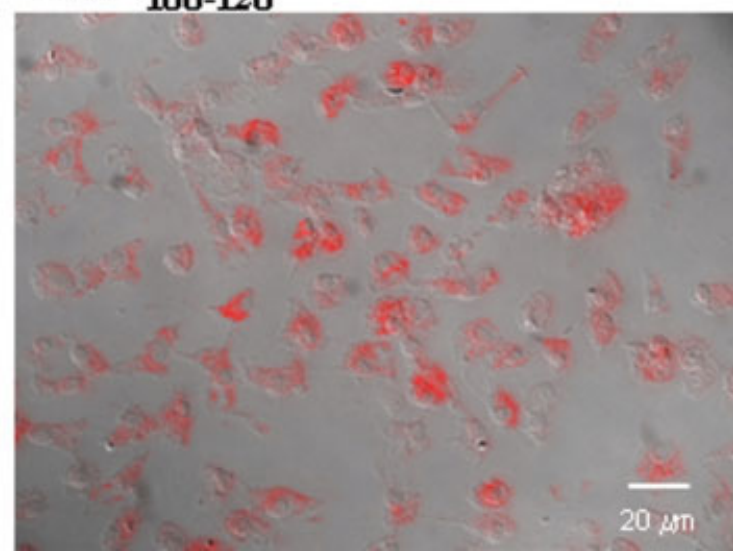

scribed in Materials and Methods. The cells were observed in contrast phase and in fluorescent view on an Axiovert 200 fluorescence microscope. Images were obtained by overlaying phase-contrast and ED-1 fluorescence (red) and are representative of each experimental condition. The same pattern of images was obtained in three or four independent experiments. Scale bars $=20 \mu \mathrm{m}$.

phenylmethylsulfonyl fluoride (PMSF), and protease inhibitor cocktail]. The lysates were rapidly frozen/defrosted three times and cleared by centrifugation $(20,200 \mathrm{~g}$ for $10 \mathrm{~min})$. The supernatant was collected and assayed for protein content with the Bio-Rad reagent. The proteins were separated by electrophoresis on 10\% SDS-PAGE and transferred electrophoretically to a PVDF membrane (Agostinho and Oliveira, 2003). To facilitate the identification of proteins, a prestained precision protein standard (Bio-Rad) was used. iNOS was detected by immunodetection using a rabbit anti-iNOS monoclonal antibody (1:500) and an alkaline phosphate-conjugated secondary antibody $(1: 20,000)$. All experiments were repeated in at least three independent cell preparations. Bands of immunoreactive protein were visualized, after membrane incubation with ECF reagent for $5 \mathrm{~min}$, on a Versadoc image system. Densities of blot bands were calculated in the Quantity One program (Bio-Rad). 


\section{Nitrite Assay}

$\mathrm{NO}$ production was determined by the nitrite $\left(\mathrm{NO}_{2}^{-}\right)$ assay with the Griess reagent $(0.1 \% \mathrm{~N}$-[1-naphtyl]ethylenediamine dihydrochloride, $1 \%$ sulphanilamide and $2 \%$ phosphoric acid). This colorimetric method is based on the measurement of $\mathrm{NO}_{2}^{-}$, a stable endproduct of the reaction between $\mathrm{NO}$ and molecular oxygen. After microglial cell incubation with peptides or LPS, culture supernatants and cell lysates $(50 \mu \mathrm{l})$ were mixed with an equal volume of Griess reagent for $15 \mathrm{~min}$ in the dark at RT, according to the method described by Huygen (1970). Absorbance was measured at $550 \mathrm{~nm}$ with a microplate reader. The nitrite concentration was determined from a sodium nitrite standard curve ranging from 0 to $100 \mu \mathrm{M}$. All experiments were performed in duplicate, in four to six independent cell preparations. The total nitrite concentration produced by microglia cells was calculated by adding the nitrites in cellular supernatant and in cell lysates.

\section{Analysis of Reactive Oxygen Species Production}

After microglia treatment with the peptides or LPS, the ROS production was evaluated through the Amplex red assay and by using a fluorescent method.

Amplex red assay. The intracellular levels of hydroperoxides, mainly $\mathrm{H}_{2} \mathrm{O}_{2}$, were measured by using the Amplex red hydrogen peroxide/peroxidase assay kit. Samples from cell lysates of microglia treated with peptides or LPS, as well as standard curve samples, were incubated with a reaction mixture that contains Amplex red reagent (10-acetyl-3,7-dihydroxyphenoxazine) and horseradish peroxidase, according to the manufacturer's instructions. All experiments were performed in duplicate, in three to six independent cell preparations. Absorbance was read at $570 \mathrm{~nm}$ in a microplate reader.

Fluorimetric DCF method. The levels of intracellular peroxides were detected with a nonfluorescent compound, $2^{\prime}, 7^{\prime}$-dichlorofluorescin diacetate $\left(\mathrm{DCFH}_{2}-\mathrm{DA}\right)$, which permeates the cells and is desterified by esterases to acid $2^{\prime}, 7^{\prime}$ dichlorofluorescin. This ionized acid is trapped in the cells and can be oxidized to fluorescent $2^{\prime}, 7^{\prime}$-dichlorofluorescein (DCF) by hydroperoxides (Cathcart et al., 1983). Microglia cells cultured in glass coverslips, after being treated with peptides or not, were incubated with $5 \mu \mathrm{M} \mathrm{DCFH}_{2}-\mathrm{DA}$, as described previously by Agostinho and Oliveira (2003). The different experimental conditions were repeated in three to six independent cell preparations. DCF fluorescence was measured at $502 \mathrm{~nm}$ excitation and $550 \mathrm{~nm}$ emission and expressed as arbitrary units.

\section{Cytokine Release Assessment}

The levels of interleukin-1 $\beta$ (IL-1 $\beta$ ) and IL-6 were determined in culture supernatants of microglia cells $(0.2 \times$ $10^{6}$ cells $/ \mathrm{cm}^{2}$ ) treated with the peptides or LPS by using enzyme-linked immunosorbent assay (ELISA) kits specific for rat IL-1 $\beta$ and IL-6. The samples of culture supernatants, controls, and standards were pipetted into microplates of these ELISA kits, according to the manufacturer's instructions (R\&D Systems). The experiments were performed in duplicate, in four to six independent cell preparations. The absorbance of formed products was measured at $450 \mathrm{~nm}$, with the correction wavelength at $540 \mathrm{~nm}$, in a microplate reader. The sample values were read off the standard curve and expressed as picograms per milliliter of cell supernatant.

\section{Neuronal Viability Evaluation}

Neuronal death was assessed by fluorescence microscopy with the fluorescent DNA stain Hoechst 33342. Dead cells (mainly apoptotic) have fragmented or irregularly stained chromatin, whereas viable cells display homogeneous staining. Neurons plated in glass coverslips were incubated for $5 \mathrm{~min}$ with $300 \mu \mathrm{l}$ of Hoechst $33342(10 \mu \mathrm{g} / \mathrm{ml})$ in the dark. After being washed with PBS, the cells were observed in a fluorescence microscope. Those cells showing irregular and relatively high blue fluorescence (dead cells) were identified from an average of 300 cells per treatment and cell batch. Each individual experiment, made in duplicate, was repeated in four different cell preparations. The cells were examined by blinded counting. Four pictures from different fields (selected randomly) were taken from each individual experiment, in which all the cells $( \pm 300)$ were counted. Data are expressed as the percentage of dead cells among the total cells counted.

\section{Statistical Analysis}

Results are expressed as means \pm SEM of the number of experiments indicated in the figure legends. Statistical significance was determined by using an analysis of variance (ANOVA), followed by Dunnett's posttests, or by using the two-tailed Student's $t$-test (as indicated in Fig. 7).

\section{RESULTS}

To characterize the activation of microglia induced by $A \beta$ and $\operatorname{PrP}$, the synthetic peptides $A \beta_{1-40}, A \beta_{1-42}$ (the major components of amyloid plaques in $\mathrm{AD}$ ), and $\mathrm{PrP}_{106-126}$ (a peptide fragment that mimics PrP ${ }^{\mathrm{Sc}}$ toxicity and forms fibrils in vitro; Combs et al., 1999) were used to stimulate cultured rat microglia cells. The scrambled $\operatorname{PrP}\left(\mathrm{PrP}_{\text {scram }}\right)$ and the reverted peptide $A \beta_{40-1}$ were used in some experiments as negative controls. In addition, the bacterial endotoxin LPS, a classic inductor of glial activation in vitro, was used as a positive control. Studies performed by our group have shown that $A \beta_{1-40}$ and $A \beta_{1-42}$ were added to cultures in a fibrillar form, which was maintained during the time periods in culture (Resende et al., personal communication). We have also observed that $\operatorname{PrP}_{106-126}$ forms fibrils, but its neurotoxic effects are independent of aggregation state (Melo et al., unpublished data). Taking into account preliminary assays in which the effect of different concentrations $(0.5-5 \mu \mathrm{M})$ of each peptide on microglia morphology and NO production was tested, we used $5 \mu \mathrm{M} \mathrm{A} \beta_{1-40}$, $0.5 \mu \mathrm{M} \mathrm{A} \beta_{1-42}$, or $25 \mu \mathrm{M} \operatorname{PrP}_{106-126}$. These concentrations induced significant microglia activation (data not shown).

\section{Morphological Alterations of Microglia}

The morphological changes of microglia induced by $A \beta$ and $\operatorname{PrP}$ peptides were visualized through phasecontrast microscopy and by assessing the immunoreactiv- 


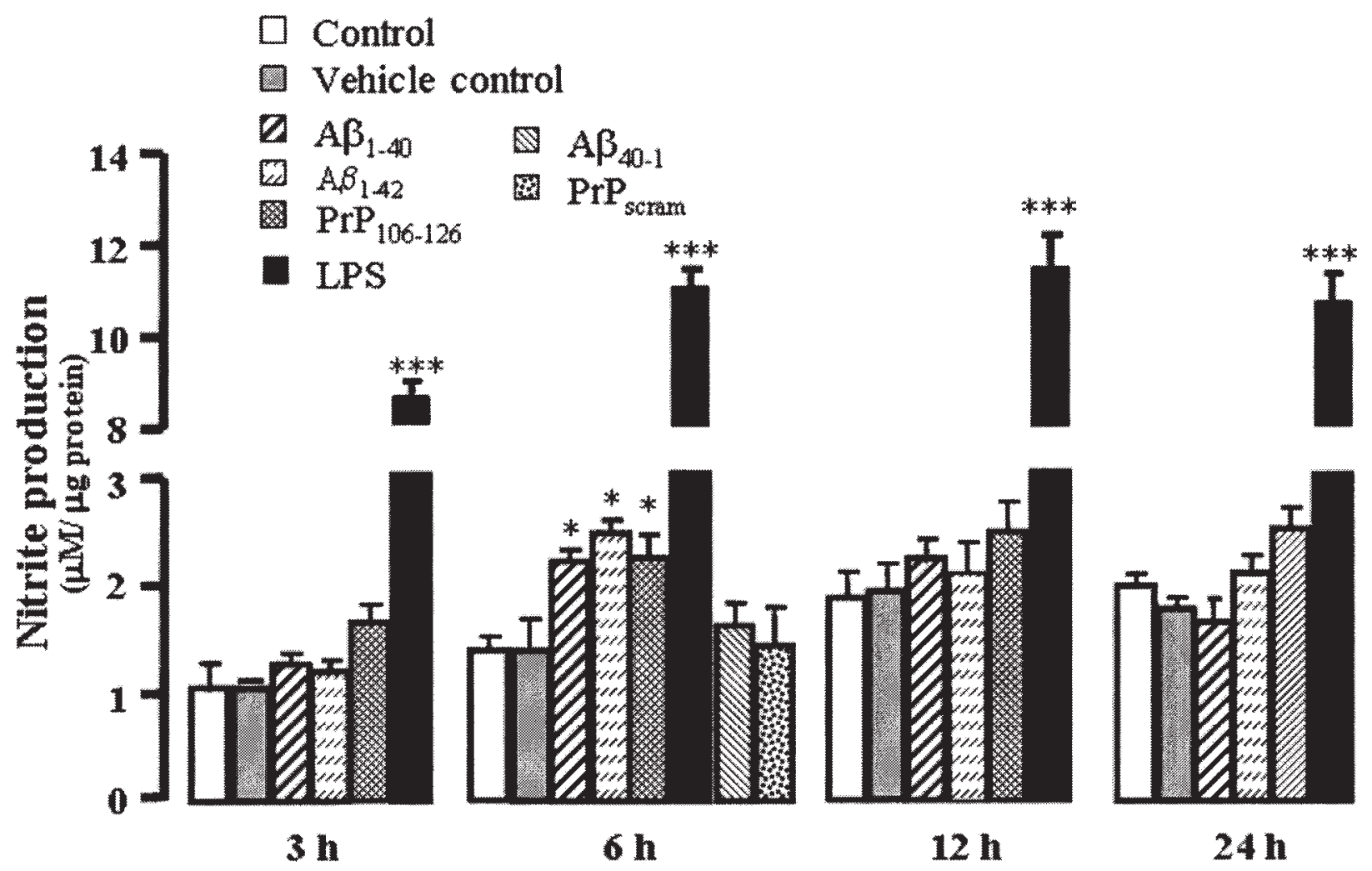

Fig. 2. Nitric oxide (NO) production by microglial cells treated with $\mathrm{A} \beta$ and PrP peptides. Cultured microglia cells were treated or not (control) with $\mathrm{A} \beta_{1-40}(5 \mu \mathrm{M}), \mathrm{A} \beta_{1-42}(0.5 \mu \mathrm{M})$, and $\operatorname{PrP}_{106-126}$ $(25 \mu \mathrm{M})$ for $3,6,12$, and $24 \mathrm{hr}$. The effects of reverted $A \beta_{1-40}$ sequence, $A \beta_{40-1}(5 \mu \mathrm{M})$, scrambled $\operatorname{PrP}_{106-126}\left(\operatorname{PrP}_{\text {scram }}, 25 \mu \mathrm{M}\right)$, and LPS $(0.1 \mu \mathrm{g} / \mathrm{ml})$ are also shown. Untreated cells (control) and cells treated with $2.1 \%$ PBS (vehicle control) were used as controls.
The concentration of nitrite, a stable NO product, was determined by the Griess assay. Values represent the total concentration of nitrite, determined in cell lysates and culture supernatants, expressed as $\mu \mathrm{M}$ / $\mu \mathrm{g}$ protein. Data are means \pm SEM of four to six independent experiments. $* P<0.05, * * * P<0.001$, significantly different from control cells under the same experimental conditions.

treatment with peptides and LPS and were maintained for at least $24 \mathrm{hr}$ (data not shown). The effect of PBS (2.1\%) was also tested on microglia morphology. PBStreated cells (vehicle control) exhibit a ramified morphology and low ED-1 immunoreactivity, similar to untreated cells (data not shown). glia cells, compared with untreated cells (control). LPS also caused alterations in microglial morphology. Microglial cells treated with $A \beta_{1-40}(5 \mu \mathrm{M}), \operatorname{PrP}_{106-126}$ $(25 \mu \mathrm{M})$, or LPS $(0.1 \mu \mathrm{g} / \mathrm{ml})$ for $3 \mathrm{hr}$ have a rounded, ameboid morphology, have phase-bright cell soma, and exhibit small and thick branches. A similar pattern of morphologic alterations was observed in microglia treated with $0.5 \mu \mathrm{M} \mathrm{A} \beta_{1-42}$ (data not shown). Control cells have an elongated shape and ramified cell bodies. Moreover, it was observed that microglia treated with peptides crowd together and form clusters, whereas control cells were dispersed. An intense immunoreactivity against ED-1 (red fluorescence) was also observed in microglia treated with peptides or LPS, compared with control cells (Fig. 1), indicating that morphological alterations induced by $A \beta$ and PrP peptides are a sign of microglia activation. These morphologic and immunophenotypic alterations became evident upon $3 \mathrm{hr}$ of

\section{Microglia Molecular Responses}

Since microglial activation also involves functional alterations, we further investigated whether $A \beta$ and $\operatorname{PrP}$ peptides affect the production and/or release of some inflammatory and neurotoxic factors.

Reactive nitrogen and oxygen species production. Figure 2 shows the levels of NO produced by cultured microglia cells treated with $\mathrm{A} \beta$ and PrP peptides for different incubation times. The levels of NO in microglia treated with $A \beta_{1-40}(1.28 \pm 0.10 \mu \mathrm{M} / \mu \mathrm{g}$ protein), $\mathrm{A} \beta_{1-42}\left(1.12 \pm 0.08 \mu \mathrm{M} / \mu \mathrm{g}\right.$ protein), and $\mathrm{PrP}_{106-126}$ $(1.65 \pm 0.20 \mu \mathrm{M} / \mu \mathrm{g}$ protein) for $3 \mathrm{hr}$ were higher than, but not significantly different $(P>0.05)$ from, those observed in control cells $(1.05 \pm 0.26 \mu \mathrm{M} / \mu \mathrm{g}$ protein). However, at $6 \mathrm{hr}$ of incubation, these peptides caused a 
significant $(P<0.05)$ increase of about $50 \%$ in the levels of NO produced compared with untreated cells (control) or PBS-treated cells (vehicle control). For longer periods of incubation, $12 \mathrm{hr}$ and $24 \mathrm{hr}$, no significant differences were observed between NO produced by $\mathrm{A} \beta$ - or $\mathrm{PrP}$ treated cells and by controls (untreated and PBS treated). At $6 \mathrm{hr}$ of incubation with $A \beta_{1-40}$ and $\mathrm{PrP}_{106-126}$, we was observed a significant increase in the amount of $\mathrm{NO}$ produced by microglia, so we analyzed whether the reverse sequence of $A \beta, A \beta_{40-1}$, and the scrambled $\mathrm{PrP}_{106-126}$ peptide $\left(\mathrm{PrP}_{\text {scram }}\right)$ affected $\mathrm{NO}$ production. In the presence of these peptides, which are not neurotoxic (Agostinho and Oliveira, 2003), the levels of NO produced were similar to the level determined in control cells, suggesting that microglia molecular responses triggered by $A \beta_{1-40}$ and $\operatorname{PrP}_{106-126}$ were specific for these amino acid sequences. The effect of $A \beta_{1-42}(0.5 \mu \mathrm{M})$ in $\mathrm{NO}$ production was similar to that obtained with $A \beta_{1-40}$ $(5 \mu \mathrm{M})$, at all incubation times studied (Fig. 2); therefore, in the following experiments, we used the smallest peptide. The effect of LPS $(0.1 \mu \mathrm{g} / \mathrm{ml})$ on NO production by microglia was also evaluated and, as expected, it was observed that this toxin significantly $(P<0.001)$ increased NO levels (Fig. 2).

To determine whether the increase in NO production caused by $A \beta$ and $\operatorname{PrP}$ peptides was correlated with alterations in iNOS expression, we determined the levels of this protein in control cells and in cells treated with $\mathrm{A} \beta_{1-40}(5 \mu \mathrm{M})$ or $\operatorname{PrP}_{106-126}(25 \mu \mathrm{M})$. We analyzed the levels of iNOS at $6 \mathrm{hr}$ of incubation, because an increase in NO production at this incubation time was observed. The results obtained via immunoblotting showed that iNOS levels in microglia treated with $\mathrm{A} \beta_{1-40}$ (1.46 \pm 0.03 a.u.) or $\operatorname{PrP}_{106-126}(1.58 \pm 0.05$ a.u.) were significantly $(P<0.05)$ higher than those determined in control cells $(1.04 \pm 0.02$ a.u $)$. LPS $(0.1 \mu \mathrm{g} / \mathrm{ml})$ also augmented $(P<0.01)$ iNOS levels (Fig. 3). To provide additional evidence that $\mathrm{A} \beta$ and $\operatorname{PrP}$ peptides affect the expression of iNOS, immunocytochemistry studies were performed to visualize the iNOS expression in cells treated with those peptides. As can be seen in Figure 4, the anti-iNOS fluorescence labelling (green) was more intense in cells treated with $A \beta_{1-40}, \operatorname{PrP}_{106-126}$, or LPS than in control cells. The images of differential interference contrast (DIC) are also displayed (Fig. 4) to show that, under control conditions, the number of cells labelled with the anti-iNOS antibody was lower than that in cells treated with the peptides or LPS. These data support those obtained from immunoblotting (Fig. 3), showing that $A \beta$ and $\operatorname{PrP}$ peptides augmented iNOS expression. This increase in iNOS expression can explain the rise in NO production observed in microglia treated with these amyloidogenic peptides (Fig. 2).

Microglial activation may involve the production of ROS that can react with $\mathrm{NO}$ forming others reactive nitrogen species (Andersen, 2004). To examine whether $\mathrm{A} \beta_{1-40}$ and $\mathrm{PrP}_{106-126}$ peptides trigger ROS production in microglia cells, we determined the intracellular hydroperoxides levels. By using the Amplex red assay, we

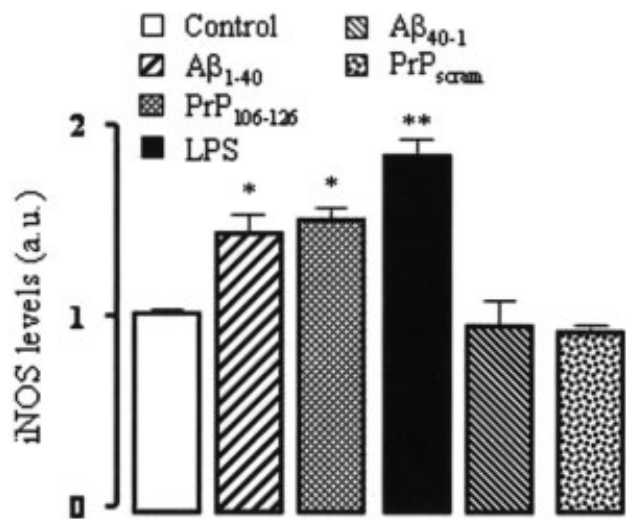

$(130 \mathrm{KDa})$

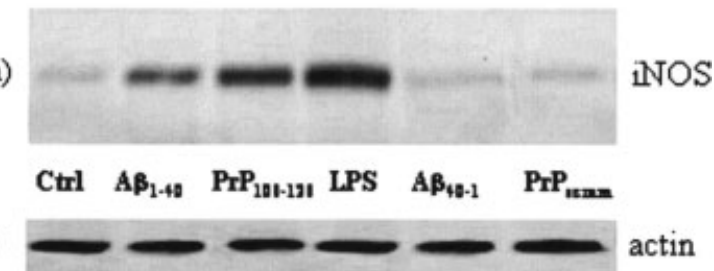

Fig. 3. Effect of $A \beta$ and $\operatorname{PrP}$ peptides on inducible $N O$ synthase (iNOS) expression. Microglia cells were treated or not (control) with $\mathrm{A} \beta_{1-40}(5 \mu \mathrm{M}), \operatorname{PrP}_{106-126}(25 \mu \mathrm{M})$, and LPS $(0.1 \mu \mathrm{g} / \mathrm{ml})$ for $6 \mathrm{hr}$. Cell lysates were examined by immunoblotting with an anti-iNOS $(130 \mathrm{kDa})$ monoclonal antibody, as described in Materials and Methods. The blot was stripped and reprobed with antiactin antibody (clone C4; Chemicon) to estimate the total amount of protein loaded in gel. Immunoreactive bands were visualized by scanning on a Versadoc Image system, and the levels of proteins were quantified in the Quantity One program. Bars represent the relative levels of iNOS, compared with actin, and were expressed as arbitrary units. Data are the means \pm SEM of three independent experiments. Representative blots of iNOS and actin are shown. ${ }^{*} P<0.05,{ }^{*} P<0.01$, significantly different from control cells.

measured the hydroperoxides levels in cell lysates of microglia treated with the peptides or LPS (Fig. 5A). The levels of ROS in microglia treated with $A \beta_{1-40}(16.4 \pm$ $1.4 \mu \mathrm{M} / \mu \mathrm{g}$ protein) and $\operatorname{PrP}_{106-126}(16.6 \pm 3.0 \mu \mathrm{M} / \mu \mathrm{g}$ protein), for $3 \mathrm{hr}$, was higher than that determined in untreated cells $(11.2 \pm 0.8 \mu \mathrm{M} / \mu \mathrm{g}$ protein). PBS (2.1\%) was without effect on ROS production (data not shown). This significant increase in ROS levels (about $46 \%$ ) was similar to that determined in microglia treated with $\mathrm{A} \beta_{1-40}$ or $\operatorname{PrP}_{106-126}$ for $6 \mathrm{hr}(50 \% \pm 2 \%)$ and $12 \mathrm{hr}$ $(48 \% \pm 2 \%)$ compared with control cells (data not shown). A significant $(P<0.01)$ enhancement in ROS levels was also observed in cells treated with LPS (Fig. 5A). A 3-hr incubation with $A \beta_{1-40}$ and $\operatorname{PrP}_{106-126}$ significantly enhanced ROS, so we monitored the ROS production in living microglia cells treated with peptides for this period. As can be seen in Figure 5B, the ROS levels produced by microglia cells treated with $A \beta_{1-40}$ or $\operatorname{PrP}_{106-126}$ were significantly $(P<0.01)$ higher than those formed in the absence of peptides. These data are in agreement with those obtained from the Amplex red assay and suggest 


\section{DIC}
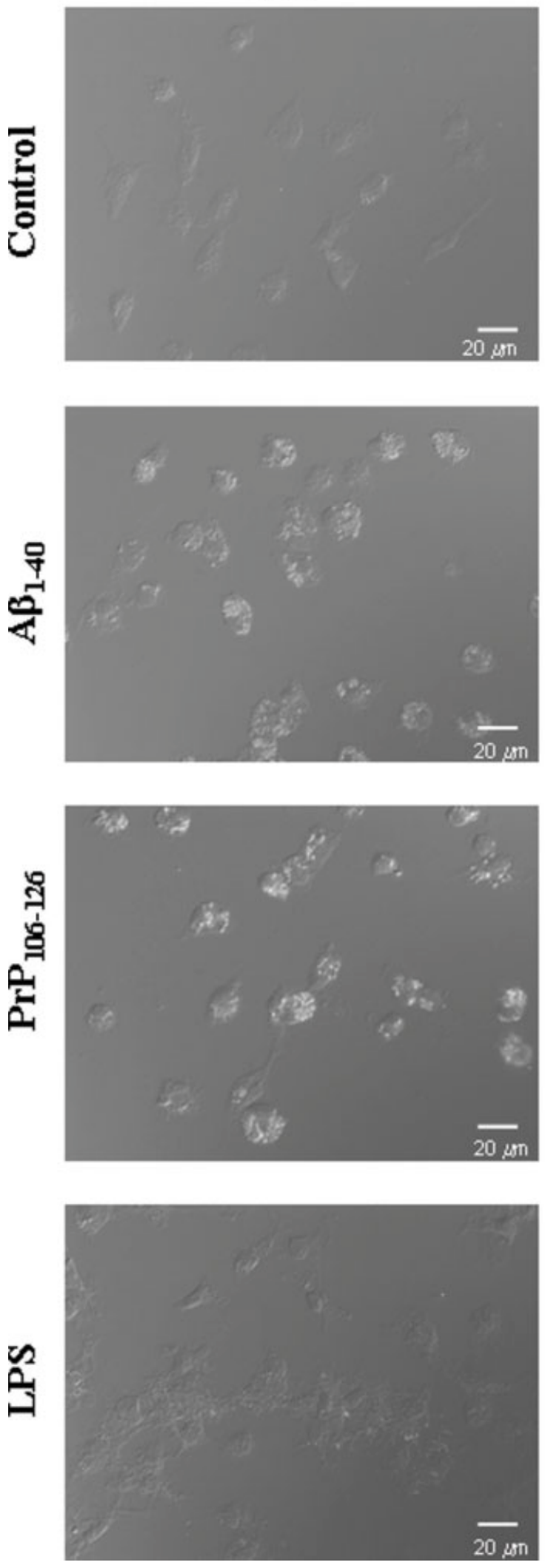

Fig. 4. Representative images of iNOS expression in microglial cells treated with $A \beta$ and $\operatorname{PrP}$ peptides. The cells were incubated with $\mathrm{A} \beta_{1-40}(5 \mu \mathrm{M}), \operatorname{PrP}_{106-126}(25 \mu \mathrm{M})$, and LPS $(0.1 \mu \mathrm{g} / \mathrm{ml})$ for $4 \mathrm{hr}$. Control cells and treated cells were immunostained with anti-iNOS (green) antibody, as described in Materials and Methods, and
anti-iNOS
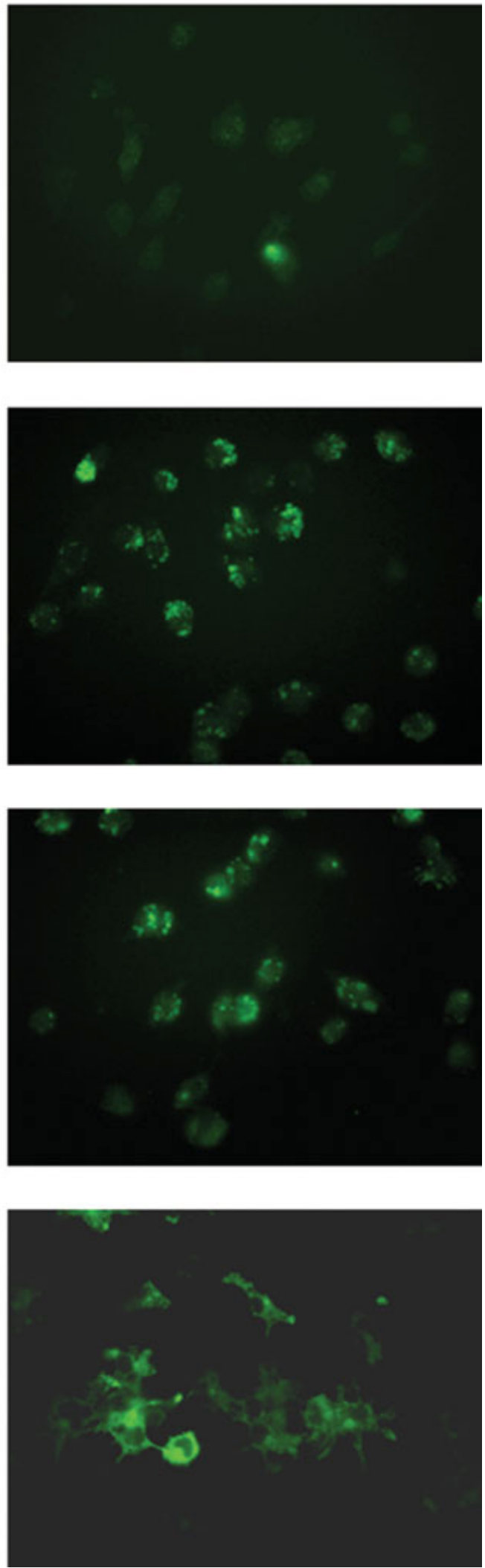

observed in fluorescent view (right column) and in differential interference contrast (DIC, left column) on an Axioskop 2 plus fluorescence microscope. The same pattern of labelling was obtained in three or four independent experiments. Scale bars $=20 \mu \mathrm{m}$. 


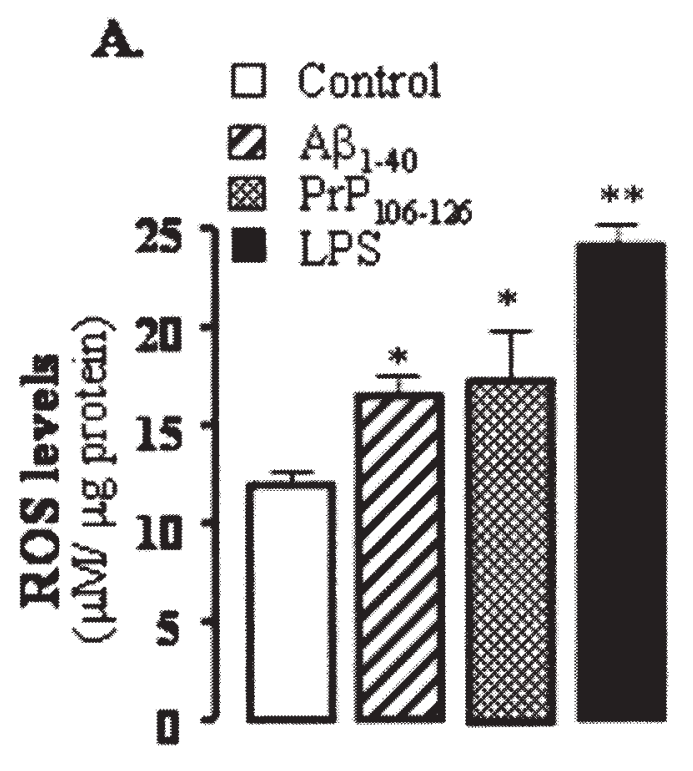

Fig. 5. Effect of $A \beta$ and $\operatorname{PrP}$ peptides on reactive oxygen species (ROS) levels produced by microglia cells. The intracellular ROS levels, mainly hydroperoxides, of microglial cells treated or not (control) with $A \beta_{1-40}(5 \mu \mathrm{M}), \operatorname{PrP}_{106-126}(25 \mu \mathrm{M})$, and LPS $(0.1 \mu \mathrm{g} / \mathrm{ml})$ were determined by using the Amplex red assay (A) and the fluorescent probe DCF $(\mathbf{B})$. Cultured microglia cells were incubated with the peptides or with LPS (positive control) for $6 \mathrm{hr}$. The quantification of ROS levels by the Amplex red assay was performed in cellular

that $\mathrm{A} \beta$ and $\operatorname{PrP}$ peptides triggered ROS production in microglia.

Cytokine secretion. In Alzheimer's and prion diseases cytokines are thought to promote $A \beta$ and $\operatorname{PrP}$ neurotoxicity (Hanisch, 2002; Hoozemans et al., 2002; Nelson et al., 2002). Therefore, we analyzed whether $\mathrm{A} \beta_{1-40}$ and $\operatorname{PrP}_{106-126}$ peptides affect the secretion of interleukin-1 $\beta$ (IL-1 $\beta$ ) and interleukin 6 (IL-6) by microglia cells. The levels of these cytokines were measured in culture supernatants of microglia treated with the peptides for $3,6,12$, and $24 \mathrm{hr}$ (Fig. 6). A $\beta_{1-40}$ increased IL-6 secretion significantly $(P<0.01)$ after $12 \mathrm{hr}$ of incubation, whereas $\operatorname{PrP}_{106-126}$ raised the secretion of this cytokine at an early phase. Indeed, as can be seen in Figure 6A, cells treated with $\mathrm{PrP}_{106-126}$ for 3-6 hr secreted significantly $(P<0.05)$ more IL-6 than under control conditions or even after $A \beta_{1-40}$ treatment. However, at $12 \mathrm{hr}$ of incubation either $\mathrm{A} \beta_{1-40}$ or $\operatorname{PrP}_{106-126}$ increased the IL-6 secretion by about $170 \%$ or $90 \%$ (above control values), respectively. These data suggest that $A \beta_{1-40}$ is more efficient in inducing IL-6 secretion than $\operatorname{PrP}_{106-126}$. The levels of IL-6 secreted by microglia treated with $A \beta_{1-40}$ or $\mathrm{PrP}_{106-126}$ for $12 \mathrm{hr}$ were not significantly different from those determined at $24 \mathrm{hr}$ of incubation, indicating that IL-6 secretion reached a plateau upon $12 \mathrm{hr}$ of
B.

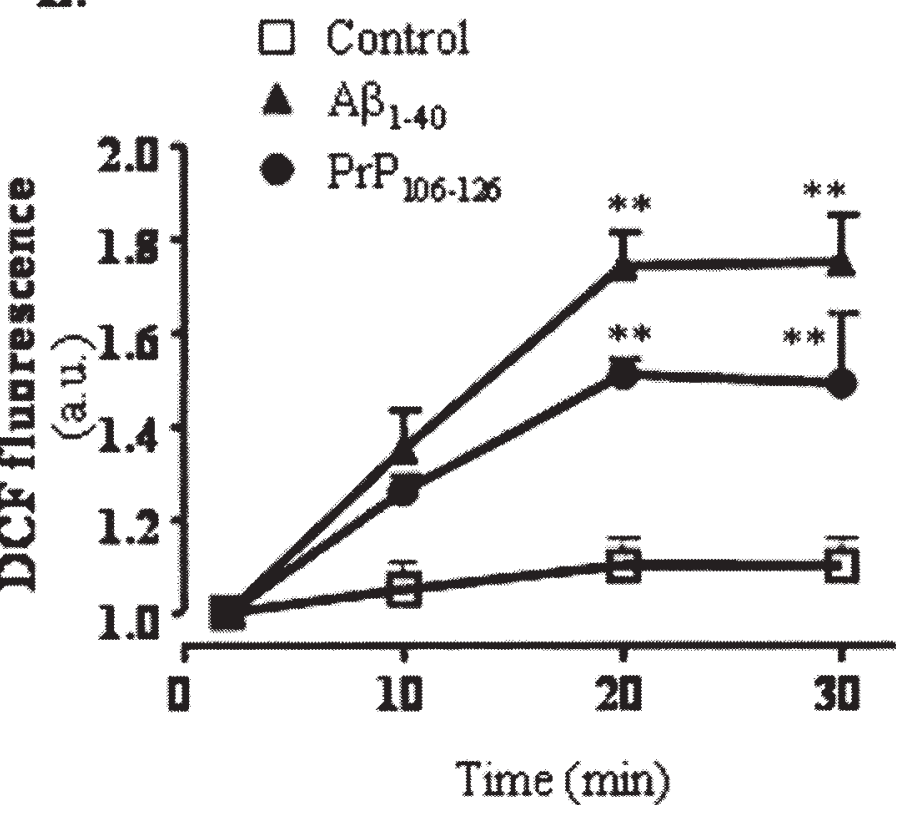

lysates. The fluorescent probe DCF monitored (for $30 \mathrm{~min}$ ) the production of ROS in living microglia cells (see Materials and Methods). The ROS levels, measured by the Amplex red (A), were expressed as $\mu \mathrm{M} / \mu \mathrm{g}$ protein and by arbitrary units of DCF fluorescence (B). Data are means \pm SEM of three to six independent experiments. ${ }^{*} P<$ $0.05, * * P<0.01$, significantly different from control cells under the same experimental conditions.

incubation with the peptides. The effect of $A \beta_{1-42}$ $(0.5 \mu \mathrm{M})$ on IL-6 secretion was also evaluated for 3,6 , 12 , and $24 \mathrm{hr}$. Similarly to what was observed with $A \beta_{1-40}$, $A \beta_{1-42}$ caused a significant increase in IL-6 secretion only after $12 \mathrm{hr}$ of incubation, the amounts of cytokine released at $12 \mathrm{hr}$ and $24 \mathrm{hr}$ being $380.5 \pm 12.7 \mathrm{pg} / \mathrm{ml}$ and $367.2 \pm 30.0 \mathrm{pg} / \mathrm{ml}$, respectively. LPS significantly increased IL-6 secretion for all incubation times studied (Fig. 6A).

Figure $6 \mathrm{~B}$ shows that IL-1 $\beta$ secretion was not significantly affected by $A \beta_{1-40}$, whereas $\operatorname{PrP}_{106-126}$ caused a significant $(P<0.05)$ increase in the release of IL-1 $\beta$ at $6 \mathrm{hr}$ of incubation. This enhancement in IL-1 $\beta$ secretion was maintained for longer incubation periods (12$24 \mathrm{hr})$. The levels of IL-1 $\beta$ secreted by microglia treated with $A \beta_{1-40}$ for $48 \mathrm{hr}$ were also determined, but no significant augmentation was observed (data not shown), suggesting that this peptide was not able to trigger IL-1 $\beta$ secretion. Likewise, $A \beta_{1-42}(0.5 \mu \mathrm{M})$, tested for 3-24 hr, did not significantly $(P>0.05)$ affect IL-1 $\beta$ release compared with control cells (data not shown). Similarly to what was observed for NO and ROS production, PBS $(2.1 \%$, vehicle control) did not affect IL-1 $\beta$ or IL-6 secretion (data not shown). Taken together, these results indicate that $A \beta_{1-40}$ and $\operatorname{PrP}_{106-126}$ affected microglial cytokines secretion in a distinct manner. 
A.

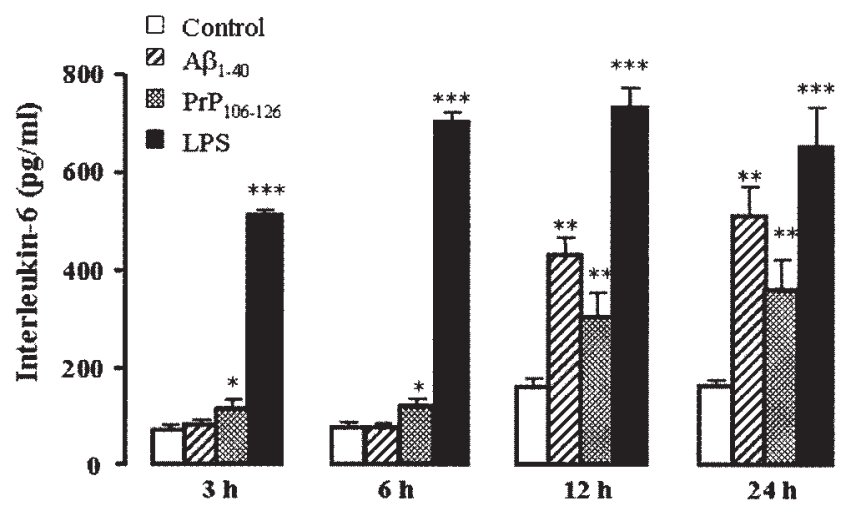

B.

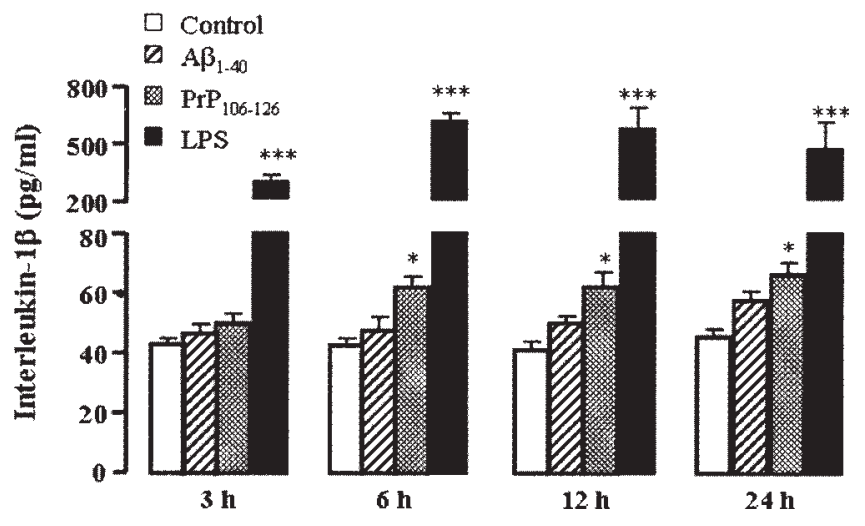

Fig. 6. Cytokines produced by microglia treated with $A \beta$ or $\operatorname{PrP}$ peptides. The cells were treated with $A \beta_{1-40}(5 \mu \mathrm{M}), \operatorname{PrP}_{106-126}$ $(25 \mu \mathrm{M})$, or LPS $(0.1 \mu \mathrm{g} / \mathrm{ml})$ for $3,6,12$, and $24 \mathrm{hr}$. The levels of interleukin-6 (A) and interleukin-1 $\beta(\mathbf{B})$, in control cells and in cells treated with the peptides or LPS, were determined in culture supernatants by ELISA, as described in Materials and Methods. The amount of cytokines released is expressed as $\mathrm{pg} / \mathrm{ml}$ cell supernatant. Data are means \pm SEM of four to six independent experiments. $* P<0.05, * * P<0.01, * * * P<0.001$, significantly different from control cells under the same experimental conditions.

\section{Neurodegeneration Caused by Microglia Activated by $A \beta$ and PrP Peptides}

To evaluate whether the substances released by $A \beta$ or PrP-activated microglia cause neuronal death, we used cocultures of microglia-neurons (Mic-Neu). $A \beta_{1-40}$ $(5 \mu \mathrm{M}), \operatorname{PrP}_{106-126}(25 \mu \mathrm{M})$, or LPS $(0.1 \mu \mathrm{g} / \mathrm{ml})$ was added to culture plate inserts containing microglia cells. In these cocultures, the substances released by microglia can reach neurons by diffusing through the membrane porous $(0.4 \mu \mathrm{m})$ of inserts. Figure 7 shows that, in cocultures treated with $A \beta_{1-40}, \operatorname{PrP}_{106-126}$, or LPS, the percentage of dead neurons was significantly $(P<0.01)$ higher than in untreated cocultures (control). These data suggest that the substances released by $\mathrm{A} \beta-$, PrP-, or LPSactivated microglia triggered neuronal death. Because we observed that microglial secretion of IL-6, but not of IL-

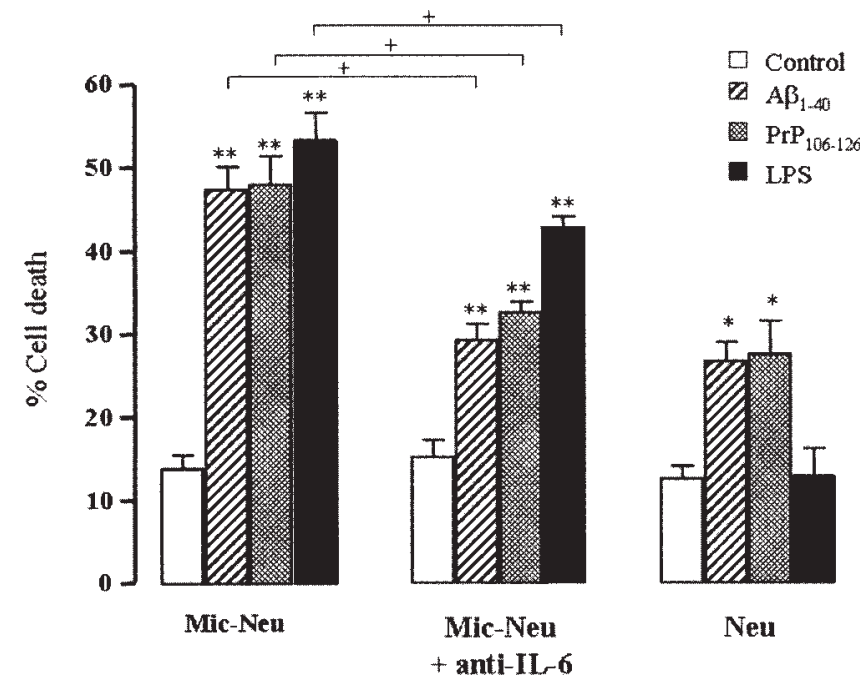

Fig. 7. Neuronal death induced by $A \beta-$ and $\mathrm{PrP}$-activated microglia in the presence or absence of a neutralizing antibody for IL-6. A $\beta_{1-40}$ $(5 \mu \mathrm{M}), \operatorname{PrP}_{106-126}(25 \mu \mathrm{M})$, or LPS $(0.1 \mu \mathrm{g} / \mathrm{ml})$ was added into inserts containing microglia cells that were cocultured with cortical neurons (Mic-Neu), for $24 \mathrm{hr}$. When the effect of anti-IL-6 antibody was tested in these cocultures system (Mic-Neu + anti-IL-6), $50 \mathrm{ng} / \mathrm{ml}$ of antibody was added to neuronal cultures just prior the treatment of microglia (in inserts) with the peptides or LPS. A similar system using inserts without cells, which were placed in wells containing the cultured neurons ( $\mathrm{Neu}$ ), was also used to determine the direct effect of peptides on neuronal viability (see Results). After incubation with the peptides or LPS in the presence or absence of antiIL-6, inserts were removed, and the neuronal cells were labelled with Hoechst 33342. The number of dead and viable cells was determined, analyzing the nuclear morphology. Data are expressed as a percentage of dead cells relative to the total number of cells counted ( \pm 300 cells per treatment and cell batch) and are means \pm SEM of four independent experiments. ${ }^{*} P<0.05, * * P<0.01$, significantly different from control cells under the same experimental conditions (Mic-Neu, Mic-Neu + anti-IL-6, or Neu); ${ }^{+} P<0.05$ compared with cells treated with the same peptide or LPS in the presence of anti-IL-6 antibody (two-tailed Student's $t$-test).

$1 \beta$, was significantly augmented by $\mathrm{A} \beta$ and $\operatorname{PrP}$ treatments, the effect of a neutralizing antibody for IL-6 was evaluated in cocultures. With the presence of the antibody $(50 \mathrm{ng} / \mathrm{ml})$, we observed a significant $(P<0.05)$ reduction (about $40 \%$ ) of neuronal death after microglia treatment with $\mathrm{A} \beta$ or PrP. The anti-IL-6 antibody also significantly $(P<0.05)$ prevented the neuronal death induced by LPS-treated microglia (Fig. 7, Mic-Neu + anti-IL-6). Similar effects were observed with $100 \mathrm{ng} / \mathrm{ml}$ anti-IL-6 antibody (data not shown). Because in these cocultures systems the peptides can diffuse through porous membrane, we determined whether $A \beta_{1-40}, \operatorname{PrP} 106-126$, and LPS added to inserts without microglia affect neuronal viability (Fig. 7, Neu). When the inserts without microglia cells were used, the $\mathrm{A} \beta_{1-40}$ and $\mathrm{PrP}_{106-126}$, but not LPS, caused significant $(P<0.05)$ neuronal injury. Although neuronal death in cocultures (Mic-Neu) could be partially due to a direct effect of the peptides on neu- 
rons, the data suggest that IL-6 released by microglia treated with $A \beta_{1-40}, \operatorname{PrP}_{106-126}$, or LPS triggered neurodegeneration.

\section{DISCUSSION}

Several studies have reported that $A \beta$ and $\operatorname{PrP}$ synthetic peptides induce microglia activation in biological models containing neurons and/or astrocytes. In these cell systems, the activation of microglia is influenced not only by the peptides but also via substances released by injured cells (Eikelenboom et al., 2002; Eskes et al., 2003). In this study, we used pure cultures of rat brain microglia cells to investigate whether $A \beta$ and $\operatorname{PrP}$ synthetic peptides, per se, differentially activate these immunoeffector cells. The microglia culture system used, despite being maintained in astrocyte-conditioned media, did not include reactive astrocytes or the multitude of other cytokines and factors released by them that certainly contribute to trigger neurodegeneration (von Bernhardi and Eugenín, 2004; Schultz et al., 2004). Moreover, the effect of substances released by $A \beta$ - and $\mathrm{PrP}$-activated microglia cells in neuronal viability was also evaluated by using cocultures, where neurons can be separated before cell death analysis. Therefore, this defined cell system can be useful in identifying initial and specific targets that might contribute to the development of therapeutic strategies to treat $\mathrm{AD}$ and PRE.

Microglia activation involves multiple pathways that result in morphological alterations, proliferation, changes in phagocytic competence, and production of bioactive molecules, which can modulate a large spectrum of functional activities (Streit et al., 1999). In this study, we observed that cultured rat brain microglia cells exposed to $\mathrm{A} \beta_{1-40}$ or $\mathrm{PrP}_{106-126}$ underwent considerable changes in morphology and ED-1 immunoreactivity in a time-dependent manner, with the alterations starting to be evident after $3 \mathrm{hr}$ treatment. The morphological and immunophenotypical alterations of microglia induced by these peptides were similar to those observed in cells treated with LPS, a strong inductor of glial activation in vitro (Fig. 1). These data suggest that $A \beta$ and $\operatorname{PrP}$ synthetic peptides induced changes in microglia morphology that are correlated with the activation process.

The substances released by activated microglia have been pointed out as essential elements in the onset and progression of neurodegenerative diseases, such as $\mathrm{AD}$ and PRE (Streit, 2002; Nelson et al., 2002; Liu and Hong, 2003). NO can be an important signalling molecule; however, when it reacts with superoxide, it can form peroxynitrite that might act as a neurotoxic factor (Fabrizi et al., 2001; Xie et al., 2002; Liu and Hong, 2003). Our results show that $A \beta_{1-40}, A \beta_{1-42}$, and $\mathrm{PrP}_{106-126}$ caused a significant peak in microglial $\mathrm{NO}$ production, at $6 \mathrm{hr}$ incubation, whereas LPS induced a huge increase in NO levels that was maintained for all incubation periods tested. Under our experimental conditions, the increases in NO production induced by $A \beta$ and $\mathrm{PrP}$ peptides were accompanied by an increase in
ROS levels, mainly hydroperoxides. Indeed, by using two different assays (DCF and Amplex red), a significant increase was observed in microglial ROS production, at a relatively early phase of peptide exposure $(3-6 \mathrm{hr})$. Xie and colleagues (2002) reported that peroxynitrite is the major mediator of the neurotoxicity induced by $A \beta-$ and LPS-activated microglia cells. The brains of AD patients exhibit high levels of nitrotyrosine, which result from the reaction of peroxynitrite with tyrosine residues of proteins (Smith et al., 1997), suggesting a participation of NO and ROS in this disorder. Moreover, ROS can promote the aggregation of amyloid fragments and consequently the formation of amyloid deposits (Van Everbroeck et al., 2004). Therefore, the early release of NO and ROS may be an essential factor in AD and PRE progression.

It is known that stressful conditions can trigger the expression of iNOS, which can generate NO from Larginine (Vallance and Leiper, 2002). We observed that $A \beta_{1-40}$ and $\operatorname{PrP}_{106-126}$, after 6 hr incubation, significantly increased the iNOS levels of microglia. Accordingly, other studies have reported that $\mathrm{A} \beta$ and $\operatorname{PrP}$ synthetic peptides induce iNOS expression, by measuring the levels of mRNA and/or of protein (Fabrizi et al., 2001; von Bernhardi and Eugenín, 2004), and it was also stated that iNOS expression is increased in the brains of $\operatorname{PrP}^{\mathrm{Sc}}{ }_{-}$ infected animals (Ju et al., 1998; Williams et al., 1997) and of AD patients (Luth et al., 2002). A great variability in the incubation time with peptides needed to induce changes in iNOS expression and NO production has been reported in different studies. These discrepancies probably are due to experimental conditions used, such as the presence of astrocytes or neurons, source (human, rat, mouse) of microglia cells, culture age and density, as well as culture media composition. Indeed, a recent study stated that $A \beta$ peptides induce higher increases in iNOS levels and NO production in pure microglia cultures than in mixed glial cell cultures (von Bernhardi and Eugenín, 2004).

Cytokines are signalling proteins that are thought to participate in several events in CNS, such as immunoregulation, intercellular communication, and neurodevelopment. IL-1 $\beta$ and IL-6 are important effector cytokines, acting as immunostimulatory and proinflammatory factors (Hanisch, 2002). Both these cytokines have been identified in amyloid plaques, near activated microglia, and it is widely suggested that they play an important role in neurodegeneration (Hanisch, 2002; Hoozemans et al., 2002; Nelson et al., 2002). Our data show that $\operatorname{PrP}_{106-126}$, but not $A \beta_{1-40}$, augmented the IL-1 $\beta$ secretion by microglia. Moreover, it was observed that IL-6 secretion was induced only by $\operatorname{PrP}_{106-126}$ at an early phase (3-6 hr), but $A \beta_{1-40}$ was more efficient than $\mathrm{PrP}_{106-126}$ for longer incubation periods, inducing a higher production of this cytokine. In accordance with our results, it was shown that $\mathrm{PrP}_{106-126}$ induces IL-6 and IL-1 $\beta$ release in cultured mouse microglia (Peyrin et al., 1999; Veerhuis et al., 2002), and fibrillar $A \beta$ is unable to induce IL-1 ( $\beta$ and $\alpha$ ) release (Li et al., 2004). 
On the contrary, it was reported that $A \beta_{25-35}$ peptide (without fibrillogenic capacity) treatment for $24 \mathrm{hr}$ induces the release of IL-1 $\beta$ but not of IL-6 (Lee et al., 2002). Recent studies have reported that the activation of human microglia and the consequent release of cytokines induced by $\mathrm{A} \beta$ and $\operatorname{PrP}$ are increased by complement factors $\mathrm{C} 1 \mathrm{q}$ and serum amyloid $\mathrm{P}$, which are usually associated with amyloid deposits in AD and PRE (Veerhuis et al., 2003, 2005). Our data suggest that microglia cells react differentially to $\mathrm{A} \beta$ and $\mathrm{PrP}$ peptides in IL-1 $\beta$ and IL-6 secretion. The differences between $A \beta$ - and PrP-evoked IL-1 $\beta$ and IL-6 release and the LPS-evoked release are remarkable, probably because peptides induce subtoxic responses, whereas the endotoxin caused an unusual and toxic response. In a paper by Combs and colleagues (1999), comparing microglia responses to $A \beta_{25-35}$ and $\operatorname{PrP}_{106-126}$, it was reported that both peptides activate identical tyrosine kinase-dependent inflammatory signal transduction cascades that lead to production of neurotoxic substances. These signal pathways are also activated by classical immune stimulus of inflammation, and their primary downstream targets are transcription factors that positively modulate the expression of proinflammatory factors (Combs et al., 1999, 2000). Our data reinforce these findings, in that we observed that microglia cells were similarly affected by $\mathrm{A} \beta$ and $\mathrm{PrP}$ peptides as concerns ROS and NO production as well as levels of iNOS expression.

Activated microglia secrete a wide range of substances, including, in addition to those already mentioned, various neurotoxic factors that could represent the outcome of a coordinated program of intracellular signalling events mediating proinflammatory and neurotoxic responses (Fabrizi et al., 2001; Hanisch, 2002). By uing cocultures of microglia-neurons, we have observed that substances released by microglia treated with $A \beta_{1-40}$ and $\operatorname{PrP}_{106-126}$, as well as with LPS, caused neuronal injury. The blockade of IL-6 physiological effects, by using a neutralizing anti-IL-6 antibody, significantly prevented the neurodegeneration caused by $\mathrm{A} \beta-, \mathrm{PrP}-$, and LPS-activated microglia. In accordance with these results, several groups have reported that IL-6 exposure compromises neuronal viability (Qiu et al., 1998; Nelson et al., 2004). On the other hand, it was also stated that this cytokine can be neuroprotective and neurotrophic in several pathological conditions (Carlson et al., 1999; Hanisch, 2002; Peng et al., 2005). Indeed, the tendency of IL-6 for a proinflammatory or an antiinflammatory effect is probably determined by its concentration and the simultaneous presence of other factors, such as cytokines. We can speculate that IL-1 $\beta$ was not involved in the neurotoxicity triggered by activated microglia because IL-1 $\beta$ secretion increased only after PrP or LPS treatments and not in $A \beta$-activated microglia, although the extent of neuronal death was similar in cocultures treated with $A \beta, \operatorname{PrP}$, or LPS. Although the data suggest that IL-6 released by microglia treated with $A \beta_{1-40}$, $\operatorname{PrP}_{106-126}$, or LPS triggered neurodegeneration, the neuronal death in cocultures could be due partially to peptide diffusion through the porous membrane of inserts, resulting in a direct effect on neurons (see results obtained when peptides and LPS were added to the insert without microglia; Fig. 7, Neu). In accordance, previous reports from our group and others show that $\mathrm{A} \beta$ and PrP peptides are neurotoxic (Combs et al., 1999; Agostinho and Oliveira, 2003).

In conclusion, our data show that $\mathrm{A} \beta$ and PrP peptides, per se, induced microglia activation and increased the production of ROS and $\mathrm{NO}$ as well as of iNOS expression. However, these peptides seemed to have a different time lag in inducing IL-6 release and dissimilar effects on IL-1 $\beta$ secretion, indicating that $A \beta$ and $\operatorname{PrP}$ differentially affect cytokines secretion by microglia. The IL-6 released by activated microglia contributes to neurodegeneration. Thus, pharmacological interventions targeting prevention of IL-6 secretion and/or its cellular effects can be useful in treating AD and PRE.

\section{ACKNOWLEDGMENT}

We thank Paula Canas (PhD student, University of Coimbra) for helpful contributions in establishing the conditions of microglia cultures.

\section{REFERENCES}

Agostinho P, Oliveira CR. 2003. Involvement of calcineurin in the neurotoxic effects induced by amyloid-beta and prion peptides. Eur J Neurosci 17:1189-1196.

Andersen JK. 2004. Oxidative stress in neurodegeneration: cause or consequence? Nat Med J SupplS18-S25

Carlson NG, Wieggel WA, Chen J, Bacchi A, Rogers SW, Gahring LC. 1999. Inflammatory cytokines IL-1 alpha, IL-1 beta, IL-6, and TNFalpha impart neuroprotection to an excitotoxin through distinct pathways. J Immunol 163:3963-3968.

Cathcart R, Schwiers E, Ames BN. 1983. Detection of picomole levels of hydroperoxides using a fluorescent dichlorofluorescein assay. Anal Biochem 134:111-116.

Combs CK, Johnson DE, Cannady SB, Lehman TM, Landreth GE. 1999. Identification of microglial signal transduction pathways mediating a neurotoxic response to amyloidogenic fragments of beta-amyloid and prion proteins. J Neurosci 19:928-939.

Combs CK, Johnson DE, Karlo JC, Cannady SB, Landreth GE. 2000. Inflammatory mechanisms in Alzheimer's disease: inhibition of betaamyloid-stimulated proinflammatory responses and neurotoxicity by PPAR gamma agonists. J Neurosci 20:558-567.

Davalos D, Grutzendler J, Yang G, Kim JV, Zuo Y, Jung S, Littman DR, Dustin ML, Gan WB. 2005. ATP mediates rapid microglial response to local brain injury in vivo. Nat Neurosci 8:752-758.

Eikelenboom P, Bate C, Van Gool WA, Hoozemans JJ, Rozemuller JM, Veerhuis R, Williams A. 2002. Neuroinflammation in Alzheimer's disease and prion disease. Glia 40:232-239.

Eskes C, Juillerat-Jeanneret L, Leuba G, Honegger P, Monnet-Tschudi F. 2003. Involvement of microglia-neuron interactions in the tumor necrosis factor-alpha release, microglial activation, and neurodegeneration induced by trimethyltin. J Neurosci Res 71:583-590.

Fabrizi C, Silei V, Menegazzi M, Salmona M, Bugiani O, Tagliavini F, Suzuki H, Lauro GM. 2001. The stimulation of inducible nitric-oxide synthase by the prion protein fragment ${ }_{106-126}$ in human microglia is tumor necrosis factor-alpha-dependent and involves p38 mitogen-activated protein kinase. J Biol Chem 276:25692-25696. 
Hanisch UK. 2002. Microglia as a source and target of cytokines. Glia 40:140-155.

Hoozemans JJ, Veerhuis R, Rozemuller AJ, Eikelenboom P. 2002. The pathological cascade of Alzheimer's disease: the role of inflammation and its therapeutic implications. Drugs Today 38:429-443.

Huygen IC. 1970. Reaction of nitrogen dioxide with Griess type reagents. Anal Chem 42:407-409.

Ju WK, Park KJ, Choi EK, Kim J, Carp RI, Wisniewski HM, Kim YS 1998. Expression of inducible nitric oxide synthase in the brains of scrapie-infected mice. J Neurovirol 4:445-450.

Kingham PJ, Cuzner ML, Pocock JM. 1999. Apoptotic pathways mobilized in microglia and neurones as a consequence of chromogranin Ainduced microglial activation. J Neurochem 73:538-547.

Lee YB, Nagai A, Kim SU. 2002. Cytokines, chemokines, and cytokine receptors in human microglia. J Neurosci Res 69:94-103.

Li M, Pisalyaput K, Galvan M, Tenner AJ. 2004. Macrophage colony stimulatory factor and interferon-gamma trigger distinct mechanisms for augmentation of beta-amyloid-induced microglia-mediated neurotoxicity. J Neurochem 91:623-633.

Liu B, Hong JS. 2003. Role of microglia in inflammation-mediated neurodegenerative diseases: mechanisms and strategies for therapeutic intervention. J Pharmacol Exp Ther 304:1-7.

Luth HJ, Munch G, Arendt T. 2002. Aberrant expression of NOS isoforms in Alzheimer's disease is structurally related to nitrotyrosine formation. Brain Res 953:135-143.

Marella M, Chabry J. 2004. Neurons and astrocytes respond to prion infection by inducing microglia recruitment. J Neurosci 24:620-627.

Nelson PT, Soma LA, Lavi E. 2002. Microglia in diseases of the central nervous system. Ann Med 34:491-500.

Nelson TE, Netzeband JG, Gruol DL. 2004. Chronic interleukin-6 exposure alters metabotropic glutamate receptor-activated calcium signalling in cerebellar Purkinje neurons. Eur J Neurosci 2:2387-2400.

Peng YP, Qiu YH, Lu JH, Wang JJ. 2005. Interleukin-6 protects cultured cerebellar granule neurons against glutamate-induced neurotoxicity. Neurosci Lett 374:192-196.

Peyrin JM, Lasmezas CI, Haik S, Tagliavini F, Salmona M, Williams A, Richie D, Deslys JP, Dormont D. 1999. Microglial cells respond to amyloidogenic PrP peptide by the production of inflammatory cytokines. Neuroreport 10:723-729.

Qiu Z, Sweeney DD, Netzeband JG, Gruol DL. 1998. Chronic interleukin-6 alters NMDA receptor-mediated membrane responses and enhances neurotoxicity in developing CNS neurons. J Neurosci 18:1044510456.
Sastradipura DF, Nakanishi H, Tsukuba T, Nishishita K, Sakai H, Kato Y, Gotow T, Uehiyama Y, Yamamoto K. 1998. Identification of cellular compartments involved in processing of cathepsin $\mathrm{E}$ in primary cultures of rat microglia. J Neurochem 70:2045-2056.

Schultz J, Schwarz A, Neidhold S, Burwinkel M, Riemer C, Simon D, Kopf M, Otto M, Baier M. 2004. Role of interleukin-1 in prion disease-associated astrocyte activation. Am J Pathol 165:671-678.

Smith MA, Richey Harris PL, Sayre LM, Beckman JS, Perry G. 1997. Widespread peroxynitrite-mediated damage in Alzheimer's disease. J Neurosci 17:2653-2657.

Streit WJ. 2002. Microglia as neuroprotective, immunocompetent cells of the CNS. Glia 40:133-139.

Streit WJ, Walter SA, Pennell NA. 1999. Reactive microgliosis. Prog Neurobiol 57:563-581.

Vallance P, Leiper J. 2002. Blocking NO synthesis: how, where and why? Nat Rev Drug Discov 1:939-950.

Van Everbroeck B, Dobbeleir I, De Waele M, De Leenheir E, Lubke U, Martin JJ, Cras P. 2004. Extracellular protein deposition correlates with glial activation and oxidative stress in Creutzfeldt-Jakob and Alzheimer's disease. Acta Neuropathol 108:194-200.

van Rossum D, Hanisch UK. 2004. Microglia. Metab Brain Dis 19:393-411.

Veerhuis R, Hoozemans JJ, Janssen I, Boshuizen RS, Langeveld JP, Eikelenboom P. 2002. Adult human microglia secrete cytokines when exposed to neurotoxic prion protein peptide: no intermediary role for prostaglandin E2. Brain Res 925:195-203.

Veerhuis R, Van Breemen MJ, Hoozemans JM, Morbin M, Ouladhadj J, Tagliavini F, Eikelenboom P. 2003. Amyloid beta plaque-associated proteins $\mathrm{C} 1 \mathrm{q}$ and SAP enhance the Abeta1-42 peptide-induced cytokine secretion by adult human microglia in vitro. Acta Neuropathol 105:135-144.

Veerhuis R, Boshuizen RS, Familian A. 2005. Amyloid associated proteins in Alzheimer's and prion disease. Curr Drug Targets CNS Neurol Disord 4:235-248.

von Bernhardi R, Eugenín J. 2004. Microglial reactivity to beta-amyloid is modulated by astrocytes and proinflammatory factors. Brain Res 1025: 186-193.

Williams A, Van Dam AM, Ritchie D, Eikelenboom P, Fraser H. 1997. Immunocytochemical appearance of cytokines, prostaglandin E2 and lipocortin-1 in the CNS during the incubation period of murine scrapie correlates with progressive PrP accumulations. Brain Res 754:171-180.

Xie Z, Wei M, Morgan TE, Fabrizio P, Han D, Finch CE, Longo VD. 2002. Peroxynitrite mediates neurotoxicity of amyloid beta-peptide1-42and lipopolysaccharide-activated microglia. J Neurosci 22:3484-3492. 